\title{
Methodology for assessing the executives' performance ensuring the healthcare companies sustainable development
}

\author{
Inna Kulkova ${ }^{1, *}$, and Aleksandra Mikhaylova ${ }^{1}$ \\ ${ }^{1}$ Ural State University of Economics, 8 Marta Str., 62, 620144 Yekaterinburg, Russia
}

\begin{abstract}
The article presents the methodological tools for the evaluation the executives' performance ensuring the companies' sustainable development: the essence and the quantitative assessment concept of the organizational leaders' performance; the performance conceptual apparatus features and assessment. The performance evaluation concept is proposed on the basis of various management theories combining, taking into account the stage of the organization's life cycle. The performance evaluation stages are shown in five blocks. An indicative approach is used to assess performance, it is quantified as an indicator which integrates particular performance indicators that characterize the goals achievement for the main managing parameters (finance, patient relations, business processes, staff training and growth, and corporate management). The indicative approach features to the integrated commercial organization heads performance assessment are shown using commercial healthcare company as an example. The lifecycle stage is reflected by modification the number, composition, weights and standards value of assessment indicators. The necessity of BSC building is justified as a reflection of the social orientation and the profit generation sustainable development for the medical organization.
\end{abstract}

\section{Introduction}

The executives' performance evaluating is one of the most difficult HR management problems [1]. The relevance of methodological tools improvement for commercial healthcare organizations executives' performance evaluating is due to several factors: the modern market environment dynamism, which requires managers to be highly adaptable and ensure high company results; serious institutional transformations, especially in social spheres, requiring new conceptual approaches to the tools formation for managers' performance assessing; the management by goals principles prevalence in the performance assessing practice, which leads to a simple employees' ranking and their condition monitoring. There is an insufficient methodological elaboration of the commercial company executives' performance assessment, the interdisciplinary approach absence and the need to form an adequate balanced scorecard; these were the primary factors which determined this issue relevance and this paper scientific and practical significance.

${ }^{*}$ Corresponding author: i.a.koulkova@mail.ru 
The purpose of this article is to develop a methodology and create tools for a comprehensive assessment of the commercial healthcare company executives' performance. The goal achievement is planned by using an interdisciplinary approach to assessment, taking into account the life cycle stage and economic dynamics; development a methodology using a KPI indicators system (healthcare companies case study).

The executives' performance assessment concept for commercial healthcare companies is proposed using various management theories combination as the basis: interactive management, management by goals, management by results and evidence-based management, taking into account the company's life cycle stage.

There are some approaches in world experience to assess the healthcare companies' effectiveness and their leaders' efficiency through a spatial comparison of health care institutions as production places that transform the available resources into valuable results. Despite an increase in the number of studies in this field of science, there is no consensus about which method to use in each situation. The executives' performance assessment is associated with the final results of the company's activities in various studies, under the following evaluation conditions: the same size of compared clinics, comparability of medical care areas, the use of financial and non-financial indicators during the assessment $[2,3,4,5,6]$. Some authors have proposed an evaluation model using a fuzzy analytical network process (FANP) to assess the healthcare organization effectiveness in order to reduce the uncertainty in this assessment [7].

Aidemark (2002) investigated the BSC in a healthcare organization as an alternative to the applied evaluation systems based on financial control to reduce the performance evaluation ambiguity [8]. Linney (1998) [9] wrote a review about finding performance evaluation forms for executives (formal lengthy evaluations, rating scales [10], a short list of goals, etc.) in the process of developing new or revising old systems. Finkelstein and Hambrick (1996) have suggested that organizational performance is a key issue for executives and that it is linked to their organizations long-term success [11]. Laine, Linna, Noro and Hakkinen (2005) considered the association between productive efficiency and clinical quality in healthcare in a long-term period [12]. Gumbus, Bellhouse and Lyons (2003) described BSC that provides a framework for measuring performance in a complex and changing medical environment by evaluating healthcare companies' financial success with financial and non-financial indicators [13]. Yang, Cheng and Yang (2005) introduced the performance evaluation methodology for the private company on the Balanced Scorecard base [14]. Grigoroudis, Orfanoudaki and Zopounidis (2012) developed a performance measurement system for public healthcare organizations, using KPI in the context of BSC methodology, based on important financial and non-financial performance indicators [5].

Healthcare company executives' performance evaluation differs in that management decisions in the healthcare sector used to be temporally, short-term used solutions nature and an orientation towards preventing large-scale social consequences [16]. Russian Industry Standards presuppose the use of five main types of companies' effectiveness economic evaluation and their leaders' assessment, taking into account world experience: COI - cost of illness; CEA - cost-effectiveness analysis; CMA - cost minimization analysis; CUA - cost-utility analysis; CBA - cost-benefit analysis [17].

\section{Methods}

The following methods were used in the research: the observation (for life cycle stage determination according to the most frequently used characteristics); the comparison (for the obtained and etalons indicators comparison); the expert method (for setting the indicators weights within the assessment blocks); the balanced scorecard forming method; 
the goals tree constructing method; the formalization method; the scoring method (the scoring model was used for the integral performance structural divisions and the whole organization heads' evaluation), the rank order method, the performance evaluation method, the standard method (for spatial comparison of the actual indicators values with the best value), the testing method (for the assessment staff satisfaction with working conditions while testing the corporate governance performance), the critical incident method (to assess the presence or absence the hygiene rules and standards violations and the doctoral and the expert commission's diagnosis rejection cases), the financial analysis methods and techniques (financial statements horizontal and vertical analysis), the coefficient method (to calculate the integral indicator), CVP analysis (for calculating the profitability threshold and the financial strength margin); the questionnaires usage (for the managers' performance evaluation in the following directions: the patient satisfaction level, the specialists' satisfaction degree with the middle medical staff work quality, employee' satisfaction with the work organization system, the financial and non-financial rewards system, staff awareness of the mission, goals, strategy of the organizational development, the staff loyalty level); the scaling (all quantitative indicator values are divided into groups and a qualitative value is assigned to each group: low, medium, high)

The information base for the study was the 2018 financial statements data of the group of surveyed commercial healthcare companies in Novosibirsk city, which were at different lifecycle stages (the Prime and the Adolescent organizational lifecycle stages).

The executives' performance evaluation process is a cyclical one which includes certain stages. The information about the organizational current state parameters and the external environment parameters is collected at the first stage and the factors that determine the company's state are identified, a list of possible risks is also determined. At the second stage, all organizational management blocks objectives are defined, a balanced system of indicators and the objectives' goal achievement degree indicators is created; algorithms for calculating indicators and factor models for their analysis are determined; the methodology for integrating indicators for the final evaluation is being formed. At the third stage, the initial information base for calculations is created; and calculations are carried out. The obtained indicators levels are compared with the recommended values, and the control action is formed at the last stage.

The study formed the author's method for a comprehensive evaluation of the commercial healthcare companies' performance and their executives with the balanced scorecard construction and its formalization through the KPI and effective contracts.

The situational factors influence should be eliminated as much as possible during the executives' performance evaluation; each single indicator should be assessed, and data about the individual employees and executives' potential level should be predicted on this basis. The evaluation process and its criteria should be as accessible as possible for the understanding by those who are being evaluated and those who conduct the evaluation; and the evaluation activities conduct should really contribute to the companies' development. The executives' performance evaluation process should be managed taking into account the external environment dynamism, the organization's life cycle stage, which involves conducting such an assessment not only with a certain frequency, but also with the most effective evaluation methods search in accordance with the organization's development dynamics.

\section{Results and Discussion}

The companies' functioning and development performance and its structural units are closely related to their executives' performance. There is no uniform approach to assess the executive's performance in the theory and corporate management practice. The 
performance evaluation analysis of commercial organizations and their structural units showed that it is often not directly related to the final organization's functioning and development performance. There is no interdisciplinary approach to assessment which combines the principles and tools of various types of management and gives a synergistic effect; the company's life cycle stage is not taken into account, and the evaluation indicators system does not always to meet the requirements for being a system and does not always to motivate executives.

The executives' performance quantitative assessment concept is based on the conception of the performance as the expected result achievement degree of managed object functioning and development; as the degree of strategic and tactical management goals achievement in key subsystems that determine the competitiveness level (market rate position; products or services quality; consumers, employees and stakeholders' satisfaction; the material, human, intellectual and financial resources usage effectiveness; innovations).

Three features of the author's approach can be named: firstly, the assessment process is based not only on general and particular principles of assessment as a management procedure, but also on a set of interdisciplinary approach principles, which combines the principles of various management tools (interactive management, HR management, management by goals, management by results, evidence-based management). Secondly, the quantitative and qualitative executives' performance assessment is formalized by using a balanced scorecard. Thirdly, the organization life cycle stage and economic dynamics conditioned by changes in the external and internal organizational environment are taken into account, when determining the criteria for quantitative and qualitative performance evaluation indicators.

Management by goals should be aimed towards identifying the discrepancy between the current life situation and the goal. Goal-setting, search for means to achieve the goal, goal formalization and implementation are linked to the overcoming this discrepancy process. Management by results should be aimed to achievement maximum results based on clear and measurable agreements. Evidence-based management should be based on facts, on the reliable and deep logic usage, on the management dogmas and misconceptions rejection. Interactive management should be aimed at building an effective team and creating personal involvement and direct employees' responsibility in solving work problems [18].

The proposed methodological approach includes a set of elements: goals, objectives, theoretical and cognitive categories, concept, regulatory assessment principles, a set of methods and techniques that provide subsystems [18]. According to L.Grainer and I.Adizes, the company's life cycles are based on the comprehension the organizational development as a living organism with the allocation of growth and aging phases, and each phase corresponds to different goals and the state of business processes and structural units. The specific HR management features at different life cycle stages affect the managers' assessing methodology. Consequently, it is necessary to take into account the organization's life cycle stage in assessing its effectiveness and efficiency, when forming a balanced scorecard and determining quantitative goals, since the management nature and its effectiveness requirements will vary.

The main goal for commercial organization is to generate profits, which is due to exactly their functioning form, but the healthcare sector has a pronounced social focus. These factors combination presupposes the creation of a self-sufficient healthcare organization striving to improve clinical efficiency without economic loss. Thus, a balanced scorecard is best suited for assessing the performance of a company and its leaders.

The balanced scorecard includes both traditional financial indicators and management effectiveness indicators in various activity areas: finance, patient relations, business processes, training and staff growth, and corporate governance. The following management blocks are assessed in this study: "Patient satisfaction with the medical services quality and 
availability"; "The management performance of the providing medical services processes"; "Effectiveness of staffing and personnel development"; "The financial management effectiveness"; "The effectiveness of the corporate governance system." Each block corresponds to a certain leader (executive director, chief physician, HR director, financial director, development director). Indicators and evaluation criteria are determined by control units. The indicator is a signal which helps to make an assessment based on comparison with bases (with the plan or with the previous period, or with the best one, etc.). The benchmark is the indicator level to strive for and which is the basis for making a decision. When comparing the assessment results with the benchmarks, there can be two outcomes: the compliance of the actual indicator value with the benchmark and non-compliance. In case of compliance, the obtained result is recorded into the analytical system. In case of nonconformity, management decisions are made and the process is repeated until the performance level meets the benchmark. A critical value is set for each indicator, upon reaching which the indicator quantitative expression becomes zero (recognized as unsatisfactory). Table 2 presents benchmarks and the indicators system scale for the executives' performance assessing (healthcare commercial organizations case study) for all five blocks at the stages "Adolescent" and "Prime" life cycle.

Table 2. The indicators system for the executives' performance evaluation (healthcare commercial organizations case study) at the "Adolescent" and "Prime" life cycle stages, block "Patient satisfaction with the medical services quality and availability" is shown in detail.

\begin{tabular}{|c|c|c|c|c|c|c|c|c|c|}
\hline \multicolumn{2}{|c|}{ Indicator } & \multicolumn{2}{|c|}{ Weight, \% } & \multicolumn{2}{|c|}{$\begin{array}{l}\text { Benchmark, } \\
\text { points }\end{array}$} & \multicolumn{2}{|c|}{ Rating scale } & \multicolumn{2}{|c|}{\begin{tabular}{|c|} 
Starting \\
threshold
\end{tabular}} \\
\hline $\begin{array}{c}\text { Adolescent } \\
\text { lifecycle stage }\end{array}$ & $\begin{array}{c}\text { Prime lifecycle } \\
\text { stage }\end{array}$ & $\begin{array}{c}\text { Ado } \\
\text { lesc } \\
\text { ent }\end{array}$ & $\begin{array}{c}\text { Prim } \\
\text { e }\end{array}$ & $\begin{array}{c}\text { Adoles } \\
\text { cent }\end{array}$ & Prime & Adolescent & Prime & $\begin{array}{c}\text { Adol } \\
\text { esce } \\
\text { nt }\end{array}$ & $\begin{array}{l}\text { Pri } \\
\text { me }\end{array}$ \\
\hline \multicolumn{10}{|c|}{ 1. Patient satisfaction with the medical services quality and availability } \\
\hline $\begin{array}{c}\text { 1.1. Patient } \\
\text { satisfaction with } \\
\text { the medical } \\
\text { services quality } \\
\text { and accessibility }\end{array}$ & $\begin{array}{c}\text { 1.1. Patient } \\
\text { satisfaction with } \\
\text { the medical } \\
\text { services quality } \\
\text { and accessibility }\end{array}$ & $25 \%$ & $20 \%$ & $\begin{array}{c}0,7- \\
25 \\
\text { points }\end{array}$ & $\begin{array}{c}0,8- \\
20 \\
\text { points }\end{array}$ & $\begin{array}{c}\text { For each } 0.05 \\
\text { deterioration } \\
\text { point minus } 5 \\
\text { points }\end{array}$ & $\begin{array}{c}\text { For each } \\
0.05 \\
\text { deterioration } \\
\text { point minus } \\
5 \text { points }\end{array}$ & 0,45 & 0,60 \\
\hline $\begin{array}{l}\text { 1.2. The } \\
\text { percentage of } \\
\text { voluntary health } \\
\text { insurance } \\
\text { patients' visits }\end{array}$ & $\begin{array}{l}\text { 1.2. The } \\
\text { percentage of } \\
\text { voluntary health } \\
\text { insurance } \\
\text { patients' visits }\end{array}$ & $20 \%$ & $20 \%$ & $\begin{array}{c}0,2- \\
20 \\
\text { points }\end{array}$ & $\begin{array}{c}0,4- \\
20 \\
\text { points }\end{array}$ & $\begin{array}{c}\text { For every } 0.05 \\
\text { deterioration } \\
\text { point minus } 10 \\
\text { points }\end{array}$ & $\begin{array}{c}\text { For every } \\
0.05 \\
\text { deterioration } \\
\text { point minus } \\
5 \text { points } \\
\end{array}$ & 0,10 & 0,20 \\
\hline $\begin{array}{l}\text { 1.3. Failure rate } \\
\text { of service }\end{array}$ & $\begin{array}{l}\text { 1.3. Failure rate } \\
\text { of service }\end{array}$ & $30 \%$ & $30 \%$ & $\begin{array}{c}<0,1- \\
30 \\
\text { points }\end{array}$ & $\begin{array}{c}<0,05 \\
-30 \\
\text { points }\end{array}$ & $\begin{array}{c}\text { For every } 0.02 \\
\text { deterioration } \\
\text { point minus } 5 \\
\text { points }\end{array}$ & $\begin{array}{c}\text { For every } \\
0.01 \\
\text { deterioration } \\
\text { point minus } \\
5 \text { points }\end{array}$ & 0,22 & 0,11 \\
\hline $\begin{array}{c}\text { 1.4. The } \\
\text { proportion of } \\
\text { substantiated } \\
\text { patient } \\
\text { complaints about } \\
\text { the provided } \\
\text { services quality }\end{array}$ & $\begin{array}{l}\text { 1.4. The } \\
\text { proportion of } \\
\text { substantiated } \\
\text { patient } \\
\text { complaints } \\
\text { about the } \\
\text { provided } \\
\text { services quality }\end{array}$ & $25 \%$ & $20 \%$ & \begin{tabular}{|c}
$<0,1-$ \\
25 \\
points
\end{tabular} & $\begin{array}{c}<0,05 \\
-20 \\
\text { points }\end{array}$ & $\begin{array}{c}\text { For every } 0.02 \\
\text { deterioration } \\
\text { point minus } 5 \\
\text { points }\end{array}$ & $\begin{array}{c}\text { For every } \\
0.01 \\
\text { deterioration } \\
\text { point minus } \\
4 \text { points }\end{array}$ & 0,20 & 0,10 \\
\hline- & $\begin{array}{l}\text { 1.5. The highly } \\
\text { satisfied } \\
\text { patients' } \\
\text { percentage with } \\
\text { the healthcare } \\
\text { quality and } \\
\text { availability }\end{array}$ & - & $10 \%$ & - & $\begin{array}{c}0,4- \\
10 \\
\text { points }\end{array}$ & - & $\begin{array}{c}\text { For every } \\
0.01 \\
\text { deterioration } \\
\text { point minus } \\
5 \text { points }\end{array}$ & & 0,2 \\
\hline To & & $\begin{array}{c}100 \\
\%\end{array}$ & $\begin{array}{c}100 \\
\%\end{array}$ & $\begin{array}{c}100 \\
\text { points }\end{array}$ & $\begin{array}{c}100 \\
\text { points }\end{array}$ & & & & \\
\hline
\end{tabular}


Table 2. Continued.

\begin{tabular}{|c|c|c|c|c|c|c|c|c|}
\hline $\begin{array}{c}\text { Total for the block "Patient } \\
\text { satisfaction with the medical } \\
\text { services quality and availability" }\end{array}$ & $20 \%$ & $20 \%$ & $\begin{array}{c}100 \\
\text { points }\end{array}$ & $\begin{array}{c}100 \\
\text { points }\end{array}$ & - & $\begin{array}{c}60 \\
\text { point } \\
\text { s }\end{array}$ & $\begin{array}{c}60 \\
\text { poin } \\
\text { ts }\end{array}$ \\
\hline \multicolumn{1}{|c|}{ In total } & $\begin{array}{c}100 \\
\%\end{array}$ & $\begin{array}{c}100 \\
\%\end{array}$ & $\begin{array}{c}500 \\
\text { points }\end{array}$ & $\begin{array}{c}500 \\
\text { points }\end{array}$ & - & $\begin{array}{c}300 \\
\text { point } \\
\text { s }\end{array}$ & $\begin{array}{c}300 \\
\text { poin } \\
\text { ts }\end{array}$ \\
\hline
\end{tabular}

A balanced scorecard has a drawback: it is more HR management tool then taking economy into account methodology, which can be eliminated by using a dynamic approach to evaluation, including an integral indicator that consolidates the evaluation process and the result.

The dynamic approach assumes the establishing weights possibility for all elemental indicators and determining the final integral performance indicator. The integral indicator reflects the chief executive officer's performance by summing the element indicators up, taking into account the importance of each one. Monitoring the executives' performance assessing results in dynamics allows to determine the commercial organization development degree (progression or degradation) in each direction (five blocks) and in total (the integral indicator).

The company's life cycle stage incorporation is reflected by changing the set of assessment indicators and their number in the assessment blocks. The later the development stage, the more indicators should be used. Also, the life cycle stage is reflected by changing the benchmarks and their threshold values, which were determined by the expert assessments method.

Requirements for the executive's performance assessment are the following: indicators and evaluation criteria should be clear to all assessment participants; information must be available to the assessment subject; a link is needed between performance indicators and the reward system. An effective contract between the employee (executive) and the employer links his/her remuneration with the provided services quality and the healthcare company efficiency. In such a contract, all payments to the head are listed with the specific KPIs that must be achieved.

A limited number of KPIs were selected from the set of balanced scorecard indicators for each of the assessment blocks based on expert opinions (three - for each individual assessment block executives, five - for the CEO). The performance indicators for the five BSC management units are used as KPIs for the CEO. The number of KPIs for different life cycle stages is assumed to be the same, the life cycle stage reflection occurs by varying the planned KPI values. The KPIs' weights were established by experts' opinion, and the weights of all KPIs for the CEO are taken in equilibrium in order to comply with the balance principle. If the planned KPI value is met or overfulfilled, the bonus is paid to the manager in fully or with an extra-bonus corresponding to the overfulfillment of the established planned KPI value. In order to avoid paying bonus in a situation when some indicators are high and others are low, the rule of zeroing the payment is applied if at least one of the indicators is below the threshold benchmark value.

\section{Conclusions}

There is no generally accepted methodological approach to commercial healthcare company executives' performance evaluation in the theory and corporate practice. The study demonstrated the possibility of applying in the assessment: interconnection of the management structure, process and result; integration of management by goals, management by results, evidence-based and interactive management; quantifying 
performance as the goals achievement degree; using an indicative approach to quantifying performance with taking into account economic dynamics and the company's life cycle stage, based on goals tree building and a balanced scorecard. The proposed executives' performance assessment is a quantitative characteristic of the commercial healthcare companies' competitiveness. The application of executives' performance evaluation for individual units and the general director in the practice can be used in the motivation system by moving to an effective contract using KPIs.

The proposed assessment concept is most adequate to the modern dynamics of the external and internal Russian market environment, characterized by a high level of competition in commercial medicine. The evaluation results can be used in the strategic, current and operational planning system of the organization's activities and in the HR management system for all decisions in the field of recruitment, motivation, training, career development, etc.

\section{References}

1. G. Yu. Barkovskaya, Human Progress, 1 (2018)

2. H. Chang, W. J. Chang, S. Das, Journal of Accounting and Public Policy, 23 (2004)

3. A. Charnes, W. Cooper, E. Rhodes, European Journal of Operational Research, 6 (1978)

4. A. De Nicola, S. Gitto. P. Mancuso, V. Valdmanis, The International Journal of Health Planning and Management, 1 (2014)

5. A. Donabedian, The Milbank Quarterly, 4 (2005)

6. L. Kuntz and S. Scholtes, The Role of Medical Professionals in Top Management Teams of Healthcare Organisations: An Economic (2008)

7. C.-R. Wu, C.-W. Chang, H.-L. Lin, Information and Management Sciences, 1 (2008)

8. L.-G. Aidemark, Financial accountability and management in governments, public services and charities, 1 (2002)

9. B. J. Linney, Career Management. Physician Executive, 6 (1998)

10. A. S. Mikhailova, Human Progress, 7 (2017)

11. S. Finkelstein and D. C. Hambrick, Strategic Leadership: Top Executives and Their Effects on Organizations (1996)

12. J. Laine, M. Linna, A. Noro, U. Hakkinen, Health Economics, 3 (2005)

13. A. Gumbus, D. E. Bellhouse, B. Lyons, The Journal of Business and Economic Studies, I.2 (2003)

14. Ch.- C. Yang, L.-Y. Cheng, Ch.-W. Yang, Human Systems Management, 4 (2005)

15. E. Grigoroudis, E. Orfanoudaki, C. Zopounidis, Omega, 1 (2012)

16. S. V. Bozhenko, O. V. Malysheva, Collection of scientific works of the Russian universities, 32. (2012)

17. V. V. Uyba, V. M. Chernyshev, O. V. Pushkarev, O. V. Strelchenko and A. I. Klevasov Economic management methods in health care (2012)

18. T. A. Vladimirova, A. S. Mikhaylova, Fundamental research, 3 (2020) 